\title{
Nehody a havárie v průmyslu
}

\section{Incidents and Accidents in Industry}

\author{
Jan Procházka*, Dana Procházková
}

ČVUT, Fakulta dopravní, Praha

\begin{abstract}
Abstrakt
Článek pojednává o nebezpečných látkách, skoro-nehodách, nehodách a haváriích v průmyslu. Shrnuje příčiny nehod a havárií a na základě analýzy konkrétních velkých závažných havárií ukazuje provázanost příčin. Shrnuje též poučení z nehod a havárií. Zdůrazňuje nutnost zavádění programu na zvyšování bezpečnosti a aplikaci získaných zkušeností pro zvyšování bezpečnosti průmyslu.

Příspěvek byl prezentován v rámci 27. mezinárodní vědecké konference Soudního inženýrství ExFoS 2018.
\end{abstract}

Klíčová slova: chemické látky, průmysl, skoro-nehoda, nehoda, havárie, příčiny, bezpečnost, program na zvyšování bezpečnosti v průmyslu, role poučení z havárií.

\section{1. ÚVOD}

Výrobky chemického, petrochemického a farmaceutického průmyslu a jiných př́buzných odvětví dnes doprovázejí člověka na každém kroku. Pomáhají mu při práci doma i v zaměstnání, přispívají k zabezpečení jeho výživy a všestranně usnadňují jeho život. Denně používáme výrobky z plastických hmot, k léčení nemocí se používají stále nové a nové léky, oblékáme se do různých oděvů zhotovených z umělých vláken apod. Život bez těchto produktů si člověk vůbec nedovede představit a používá je naprosto samozřejmě, aniž si uvědomuje celý proces, jak vznikaly.

Zvláštní pozornost vyvolávají nehody a havárie s přítomností nebezpečných chemických látek, at' už vznikají přímo v chemickém průmyslu nebo v jiných odvětvích, jako je např. obchod (skladování chemických látek) nebo doprava. Je to tím, že navzdory nesmírnému významu moderní chemie a chemické technologie pro život lidské společnosti, která její pozitivní projevy (např. umělé hmoty, pohonné hmoty, umělá hnojiva, potravinářství atd.) považuje za samozřejmost, je úroveň znalostí chemie ještě nedostačující, protože je spojena s jevy jako jsou požár, výbuch nebo toxický

\begin{abstract}
:
The paper deals with dangerous substances, near-misses, incidents and accidents in industry. It summarizes causes of incidents and accidents, an on the basis of analysis of real great significant accidents it shows linkage of causes. It also summarizes the lessons learned from incidents and accidents. It stresses the need of introduction of programme for improvement of safety and application of obtained experiences for industry safety improvement.

The paper was presented on the $27^{\text {th }}$ International Scientific Conference of Forensic Engineering, ExFoS 2018.
\end{abstract}

Keywords: chemical substances, industry, near-miss, incident, accident, causes, safety, programme for safety increase in industry, role of lessons learned from accidents it shows linkages of causes.

rozptyl, jejichž dopady na okolní prostředí způsobují značné ztráty a škody a tím i obavy. Přitom se každá látka chová pouze takovým způsobem, který odpovídá jejich přirozenosti.

Závažnost dopadů úniků nebezpečných látek na člověka a okolní prostředí se odvíjí přímo úměrně od jejich množství. Je pouze na lidech, aby zajistili bezpečnou výrobu a využívání všech látek a zároveň na nejnižší možnou míru snížili jimi způsobené nepřijatelné dopady, jednak prostřednictvím vysoce specializované technické disciplíny, jakou je bezpečnostní inženýrství a jednak také tím, že se pozvedne vědomostní úroveň společnosti jako celku.

\section{SOUHRN POZNATKŮ}

Ještě v nedávné minulosti byl předmět chemického inženýrství běžně uváděn jako procesy a aparáty $\mathrm{v}$ chemickém průmyslu. Logika věci tkví v tom, že chemické průmyslové procesy, tj. chemické reakce doprovázené sdílením hmoty a energie, probíhají ve strojnicky konstruovaných zařízeních (reaktory, výměníky tepla, destilační kolony, odparky, pece atd.) vzájemně propojených 
potrubími s uzavíracími a regulačními ventily a proudění látek v tomto komplexu je zajišt'ováno kompresory nebo čerpadly. Na začátku a na konci každého výrobního zařízení se obvykle nacházejí další strojnická zařízení, jako jsou skladovací zásobníky surovin a konečných produktů - výrobků. Celý tento komplex jednotlivých aparátů je dále vybaven prvky měření a regulace nejrůznějších veličin (tlak, teplota, výška hladiny, průtok apod.) a prvky bezpečnostních a ochranných systémů (např. pojistné ventily apod.). Není vzácností, ale spíše pravidlem, že se výrobní linky (většinou obvykle nazývané jako zařízení na výrobu např butadienu nebo styrenu jako výchozích surovin pro výrobu umělých pryží) skládají z desítek až stovek jednotlivých aparátů.

Pro podporu bezpečnosti se dnes naopak doporučuje složitá zařízení vhodně rozdělit na nižší celky, tzv. odstavitelné sekce, které lze v okamžiku nehody oddělit ručně nebo dálkově (v současnosti většinou i automaticky) od ostatní technologie. Tím lze omezit v nejhorším př́ípadě únik chemických látek pouze na obsah postižené sekce, pokud mu nelze přímo zamezit např. odvedením chemické látky na polní hořák. Pro některá zařízení se z důvodu bezpečnosti doporučuje další dělení na podsekce.

Velmi často se vyskytne otázka, zda se zajištění bezpečnosti nechá provést bez chemiků. Nemalá část provozovatelů podniků, ve kterých se chemické látky převážně pouze používají, si dosud myslí, že chemik v týmu není třeba. Není to pravda. Vezme-li se v úvahu množství a rozmanitost chemikálií, které jsou běžně v současnosti používány, odhad jejich chování v okolním prostředí po jejich úniku na základě jejich vlastnosti může nejspolehlivěji odhadnout pouze chemik. Velmi názorná odpověd' vyplývá ze zvážení p-T diagramu chemické látky (obr. 1). Každá čistá

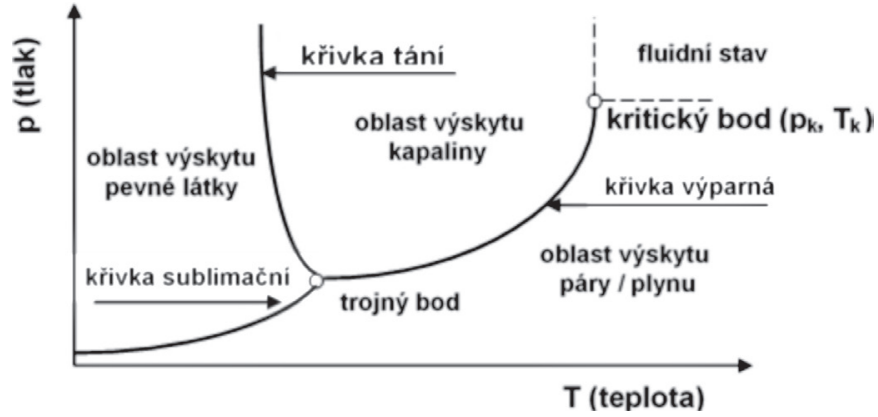

Obr. 1 Př́klad fázového idealizovaného (stavového) $p$-T diagramu čisté chemické látky.

Fig. 1 Example of phase idealized (state of matter) p-T diagram of pure chemical substance.

chemická látka je charakterizována svými fyzikálně-chemickými konstantami, např̀ bodem tání (teplota, při které přechází chemická látka ze stavu pevného do stavu kapalného), bodem varu (teplota, při které tlak nasycených par chemické látky dosáhne hodnoty 101.325 $\mathrm{kPa}$ ), trojným bodem (teplota, při které koexistují všechny tři stavy látky: pevný, kapalný i plynný) a kritickým bodem (tento bod na fázovém diagramu zakončuje křivku vypařování; v kritickém stavu charakterizovaném kritickým tlakem $p_{k}$, kritickou teplotou $T_{k}$ a kritickým objemem $V_{k}$ mizí rozdíl mezi kapalinou a její párou). Předmětné body pak propojují křivky fázových přeměn: křivka sublimační (přechod ze skupenství pevného do plynného), křivka výparná (přechod ze skupenství kapalného do plynného) a křivka tání (přechod ze skupenství pevného do kapalného).

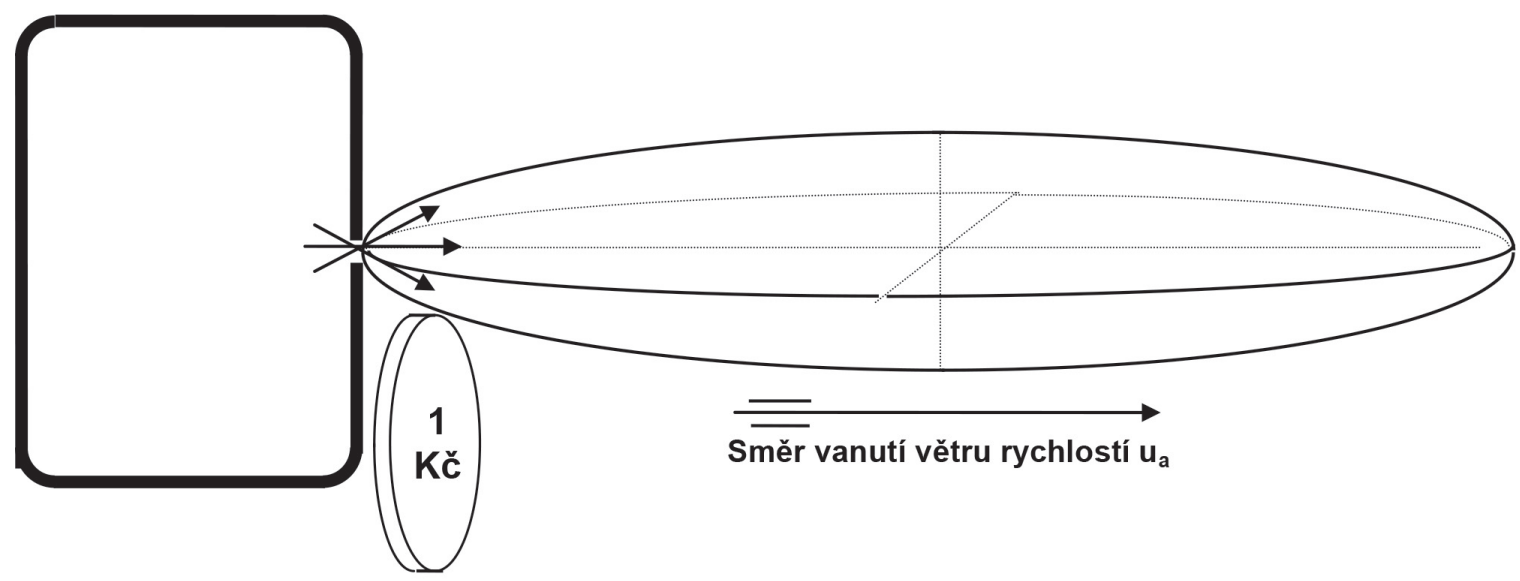

\footnotetext{
Chemická látka v zařízení pod kontrolou:

a) stav látky určen teplotou $\mathbf{T}$, tlakem p, objemem V (koncentrací c),

b) zpracování, skladování nebo transport látky přináší užitek (+ peníze).
}

\section{PŘEDMĚT CHEMICKÉHO INŽENÝRSTVÍ}

\section{Chemická látka v okolí zařízení mimo kontrolu:}

a) stav určen teplotou atmosférickou $\mathbf{T}_{\mathrm{a}}$, tlakem atmosférickým $p_{a}$, objemem oblaku $v$ atmosfére $\mathbf{V}_{\mathbf{a}}$, který je obecně funkcí původní koncentrace látky $\mathbf{c}$, rychlosti vanutí větru $\mathbf{u}_{\mathrm{a}}$, a doby trvání události $\mathbf{t}\left(\mathbf{V}_{\mathrm{a}}=\mathrm{f}\right.$ $\left.\left(\mathbf{c} . \mathbf{u}_{\mathrm{a}}, \mathbf{t}\right)\right)$,

b) únik látky do okolního prostředí zpưsobuje škody na zdraví a životě lidí, na majetku, na životním prostředí (peníze).

\section{PŘEDMĚT BEZPEČNOSTNÍHO INŽENÝRSTVÍ}

(včetně navržení a realizace zmírňujících opatření)

Obr. 2 Chemické a bezpečnostní inženýrství jsou dvě strany jedné mince [1].

Fig. 2 Chemical and security engineering are two sides of one coin [1]. 
Pouze člověk důkladně znalý chemie a fyziky má vědomosti a zná prameny, ve kterých lze nalézt informace o tom, jak odhadnout chování nebezpečné chemické látky z jejích stavových parametrů a fyzikálně-chemických konstant. Např. pokud při kryogenním skladování kapalného kyslíku $\left(t=-183^{\circ} \mathrm{C}, p=101,325 \mathrm{kPa}\right)$ dojde $\mathrm{k}$ jeho úniku do okolí charakterizovaného normálními podmínkami $\left(t=0{ }^{\circ} \mathrm{C}, p=101.325 \mathrm{kPa}\right)$, pak nastane prudký okamžitý odpar a pokles tlaku kyslíku na úroveň jeho parciálního tlaku $\mathrm{v}$ atmosféře $(\approx 21 \mathrm{kPa})$. Jev je zviditelněn kondenzací vodní páry přítomné $\mathrm{v}$ atmosfére a $\mathrm{v}$ rámci daného oblaku existuje nebezpečí vzniku omrzlin. V závislosti na meteorologických podmínkách je průměr oblaku 5 až $25 \mathrm{~m}$. Za uvedenou hranicí se vyskytuje už jen normální atmosféra s koncentrací kyslíku $21 \%$ objemu.

$\mathrm{Na}$ druhé straně chemické a bezpečnostní inženýrství jsou dvě strany jedné mince, jak je znázorněno na obr. $2[1,2]$. Uvedené skutečnosti jsou zde prezentovány pro ilustraci, aby nevznikl dojem, že zajištění bezpečnosti je celkem jednoduchá záležitost, jak se projevilo při odborném posuzování bezpečnostních dokumentací vyžadovaných od provozovatelů podle původního zákona č. 353/1999 Sb., o prevenci závažných havárií s přítomností chemických látek, a projevuje se i dále při posuzování podle zákona č. 59/2006 Sb.

Ohrožení od průmyslových komplexů, skladů a vozidel nakládajících s nebezpečnými chemickými látkami je vlastně velikost nehody (případně z ní vyvinuté havárie), která je měřena velikostí dopadů na chráněné zájmy (aktiva), tj. způsobenými škodami a ztrátami $[2,3]$. To znamená, že ohrožení souvisí s nebezpečností zařízení, která vyplývá z vnitřních (vrozených) vlastností předmětných nebezpečných chemických látek a chemických př́pravků. Rozdíl mezi ohrožením a nebezpečností je v tom, že:

- nebezpečnost všech typů zařizení s nebezpečnými chemickými látkami závisi jen na vnitřnich přičinách, tj. jenom na vlastnostech chemických látek a na procesech nakládání s nimi,

- ohrožení všech typư zařizení s nebezpečnými chemickými látkami závisí jak na vnitřnich prričinách spojených s vlastnostmi chemických látek, tak na vnitřnich príčinách spojených např. se stárnutím materiálu zařizeni, ř́zením technologických procesů, lidskými chybami apod., a tak i na vnějších př́činách (živelní pohromy, havárie jiných zařizení, domino efekty, kriminalita apod.).

V současné době je poznání takové, že rizika od všech typů zařizení s nebezpečnými chemickými látkami počítáme s ohledem na ohrožení (anglicky hazard). Jestliže se vezme v úvahu jen nebezpečnost, pak stanovené riziko není úplné, což ukázala např. Spolana a. s. při povodni v r. 2002, při které se odhalilo, že v bezpečnostní dokumentaci nebyla povodeň považována za možný zdroj havárie. Situace je však složitější. Riziko totiž ještě závisí na místní zranitelnosti, která je spojena s podložím místa, stavbou a konkrétní technologií, počtem lidí a kulturou bezpečnosti. Postupy pro identifikaci ohrožení a pro výpočet integrálního rizika lze nalézt ve specializované literatuře [2-4]. Při výpočtu ohrožení se zdroje rizika rozdělují na:

- technologické poruchy a nehody (tzv. vnitřní) kritických prvků, vazeb a toků v systému; je nutno zvážit vady materiálu, stárnutí, nedostatečnou údržbu apod.,
- chyby nebo selhání rídicího systému,

- lidské chyby,

- živelní pohromy nebo technologické havárie (tzv. vnější) jiného systému,

- teroristický útok, kriminální čin nebo válka.

a u výpočtu nebezpečnosti se zdroje rizik zvažují jen ve spojitosti $\mathrm{s}$ vlastnostmi nebezpečné látky a ostatní se neberou v úvahu, tj. dle materiálů OECD $2[5,6]$ se počítá jen tzv. chemické riziko. Mnohdy se zapomíná i na chyby spojené s řízením, tj. na organizační havárie.

V lidském systému u zařízení s nebezpečnými chemickými látkami pak rozlišujeme stavy bezpečí a nebezpečí, přičemž nebezpečí je stav, při kterém již zařízení s nebezpečnými chemickými látkami je v situaci, že újma na chráněných zájmech je vysoce pravděpodobná, tj. v daném př́padě lze s velkou pravděpodobností očekávat vznik nehody, při které budou i nepřijatelné dopady, tj. nehoda přeroste $\mathrm{v}$ havárii.

\section{NEBEZPEČNOST ZAŘÍZENÍ}

Nebezpečnost sledujeme u: technologických výrobních zařízení, skladovacích zařízení, produktovody, mobilní přepravní zařízení), která obsahují nebezpečné chemické látky.

Za velmi nebezpečná chemická zařízení, tj. za zařízení s velkou nebezpečností, jsou obecně považována taková stacionární zařízení, ve kterých dopady nehod v procesních nebo skladových zařízeních/aparátech, které se vyvinou v havárie, mohou významně ovlivnit životy nebo zdraví lidí, jejich majetek a životní prostředí za hranicemi těchto zařízení. V př́ípadě zařízení a objekti̊ skladujících nebo zpracovávajících chemické látky se zejména jedná o objekty, ve kterých se nebezpečné látky (vyjmenované jednak taxativně, jednak skupinově na základě určitých vlastností) vyskytují v množstvích převyšujících stanovené limity (viz např. směrnice Seveso II).

Po uvolnění látky ze zařízení (aparátu) mohou, jak již bylo dřive řečeno, nastat tři základní nebezpečné situace: požár (např̀. požár kaluže, tryskový oheň, ohňová koule, bleskový oheň apod.), výbuch (ohraničeného oblaku par, neohraničeného oblaku par, kondenzované fáze, expandujících par vroucí kapaliny neboli BLEVE apod.) a toxický rozptyl.

Potenciál způsobit škody je všem nebezpečným chemickým látkám „vlastní“, nebo také „vrozený či inherentní“. Je projevem jejich konkrétních vlastností, jako jsou hořlavost, výbušnost (směsí jejich par s ovzduším nebo kyslíkem) a toxicita. Chemické látky, které se v zařízeních chemického průmyslu (výrobních nebo skladových), př́ípadně v transportních prostředcích, chovají stavově, tj. zaujímají př́slušný objem a vykazují příslušný rovnovážný tlak svých par odpovídající teplotě v zařízení, se po úniku do okolí pochopitelně rovněž zachovají stavově, pouze hodnoty stavových veličin se diametrálně změní tak, že tlak a teplota budou funkcí momentálního počasí (alespoň v prvních okamžicích rozvoje události) a objem bude určován v př́ípadě úniku kapalin stavebním řešením okolí zařízení (terén, jímka apod.) a v případě plynů nebo par bude též určen momentálním počasím (viz obr. 3).

Na obr. 3 je znázorněno fyzikální chování chemických látek po jejich úniku z aparátu do okolního prostoru. Chemické látky mohou obecně vytékat z aparátů jako plyny, chladem nebo tlakem 


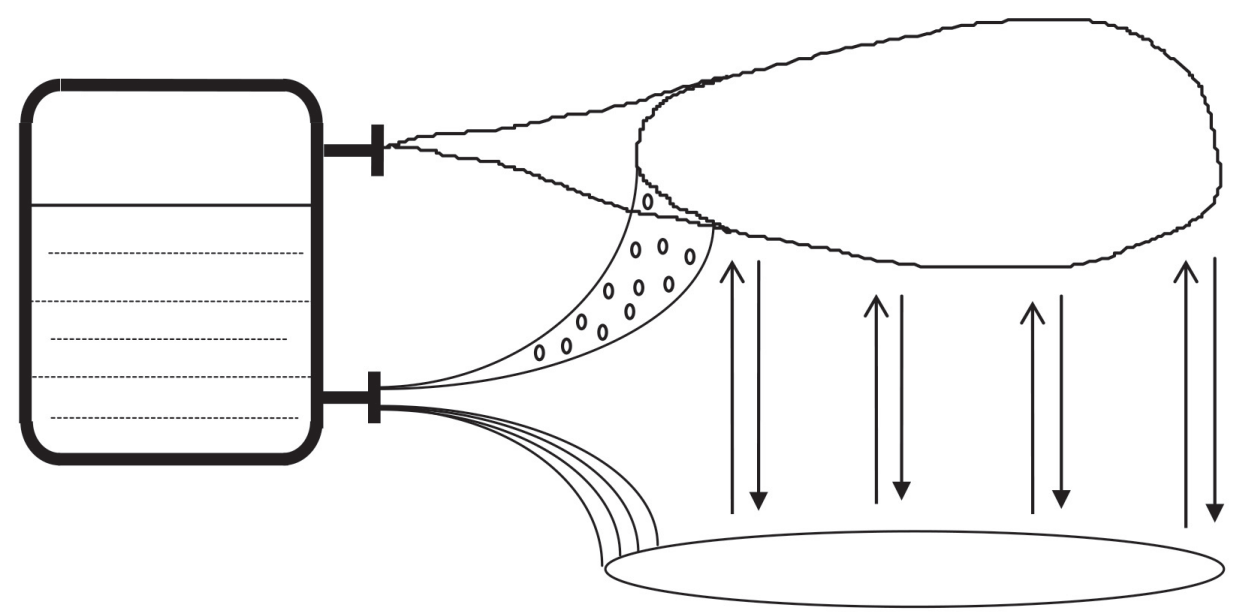

Zařizzení s chemickou látkou (obecně tekutinou):

a) stlačený plyn,

b) plyn zkapalněný tlakem nebo chladem,

c) kapalina $v$ rovnováze se svou nasycenou parou
Nežádoucí únik chemické látky:
a) výtok plynu nebo páry,
b) dvoufázový výtok (plyn/pára a kapénky kapaliny), c) výtok kapaliny.

\section{Chování chemické látky v okolním prostředí:}

a) tvorba oblaku plynů/par (nebezpečí vzniku požáru, výbuchu, toxického rozptylu),

b) kondenzace plynů / par do kaluže (nebezpečí znečištění půdy, vody),

c) tvorba kaluže a její odpar do oblaku

Obr. 3 Základní model pro odhad množství nebezpečné chemické látky, které uniklo ze zařizení do životniho prostředí; zpracováno dle [7]. Fig. 3 Basic model for judgement of amount of dangerous substance, which released from facility to environment; processed according to [7].

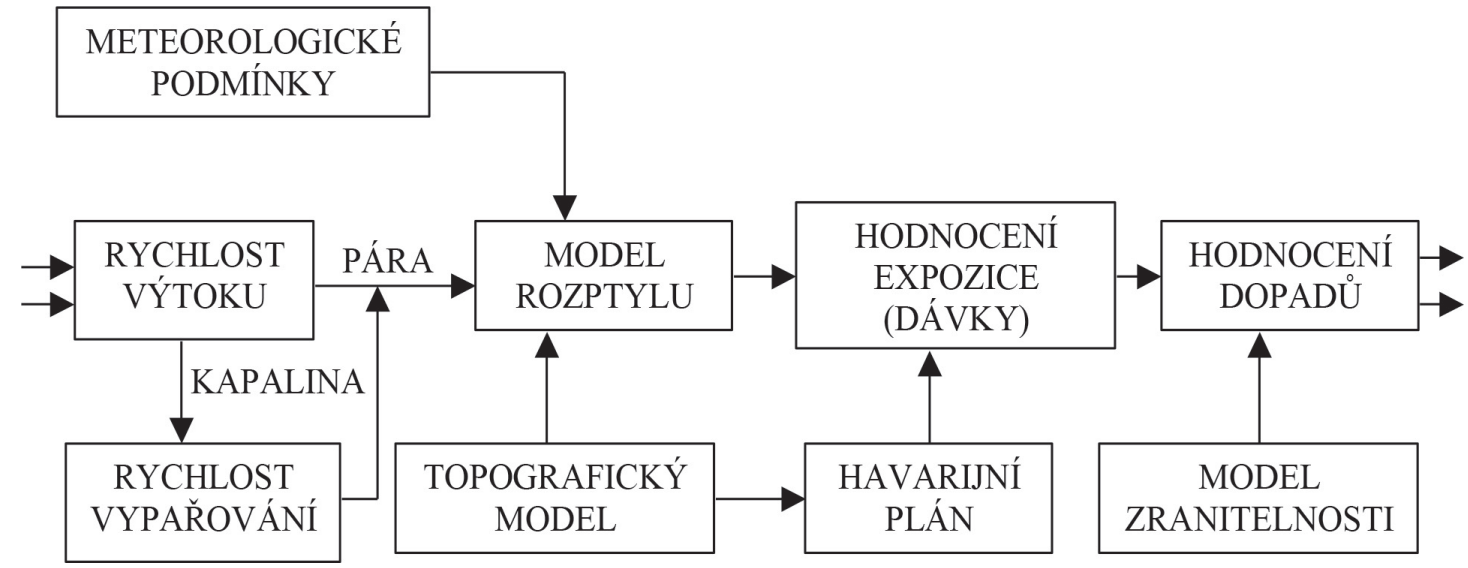

Obr. 4 Struktura modelù hodnocení dopadü.

Fig. 4 Structure of models for impacts assessment.

zkapalněné plyny nebo jako kapaliny. Protože každá taková chemická látka může mít více nebezpečných vlastností, výsledné působení může být značně komplexní (viz obr. 3 a 4).

Skutečné závažné havárie $\mathrm{v}$ chemickém průmyslu představují ve větší či menší míře nejrůznější kombinace výše uvedených základních situací. Proto je každá konkrétní nehoda i havárie vždy poněkud jiná a odlišuje se od dosud známých havárií. Proto je třeba při odhadu rizika provozu zařízení vycházet ze zcela konkrétních a co nejúplnějších údajů.

\section{VÝSLEDKY ANALÝZY PŘíČIN PRŮMYSLOVÝCH NEHOD}

Při studiu byla použita data z konkrétních havárí a ze zpráv od vyšetřovacích cílů i z vlastních zkušeností autorky, získaných při šetření havárií $[1,8]$. Velmi podrobně byly zváženy havárie Flixbourgh, Seveso a Bhópal, pro které jsou v odborné literatuře dostupná fakta $\mathrm{v}$ dostatečné podrobnosti (souhrn dat je $\mathrm{v}[1,8])$. Získaná data byla analyzována metodami 
Tab. 1 Klasifikace faktorů, které přispívaji ke vzniku závažných havárii v chemickém průmyslu.

Tab. 1 Classification of factors that contribute to strong accident origin in chemical industry.

\begin{tabular}{ll}
\hline I. & Bezprostřední přímé příčiny havárie: \\
\hline I.1 & Chyby provozovatele: \\
& I.1.1. Při provozu. \\
& I.1.2. Při údržbě. \\
& I.1.3. Při inspekci, testování nebo kalibraci. \\
& I.1.4. Při návrhu konstrukčního řešení. \\
\hline
\end{tabular}

I.2. Poruchy komponent:

I.2.1. Potrubí a potrubní prvky.

I.2.2. Svařováním.

I.2.3. Ventily.

I.2.4. Hlavní aparáty:

I.2.4.1. Nádoby / kolony.

I.2.4.2. Zásobníky.

I.2.4.3. Reaktory.

I.2.4.4. Výměníky tepla.

I.2.4.5. Pece.

I.2.4.6. Vařáky.

I.2.5. Strojní zařízení:

I.2.5.1. Čerpadla.

I.2.5.2. Kompresory / dmychadla.

I.2.5.3. Míchadla / směšovače.

I.2.5.4. Mlecí aparáty.

I.2.5.5. Mechanické dopravníky.

I.2.5.6. Sušičky.

I.2.5.7. Odstředivky.

I.2.6. Komponenty měření a regulace.

I.2.7. Elektrické komponenty.

I.3. Koroze:

I.3.1. Vnitřní koroze.

I.3.2. Vnější koroze.

I.3.3. Koroze napětím.

I.3.4. Koroze cyklickou únavou.

I.4. Nepředvídané reakce:

I.4.1. Neovladatelné / rozkladné reakce.

I.4.2. Ostatní nepředvídané chemické reakce.

I.4.3. Fyzikálně-chemické reakce.

\begin{tabular}{|c|c|c|}
\hline I.5. & \multicolumn{2}{|c|}{ Elektrostatické náboje. } \\
\hline \multirow[t]{10}{*}{ I.6. } & \multicolumn{2}{|c|}{ Události v místě nesouvisící se zařízením: } \\
\hline & I.6.1. & $\begin{array}{l}\text { Vliv domino efektu na zařízení následkem události } \\
\text { v jiném zařízení téhož podniku. }\end{array}$ \\
\hline & I.6.2. & Poruchy dodávek pomocných látek a energií: \\
\hline & & I.6.2.1. Výpadek elektřiny. \\
\hline & & I.6.2.2. Porucha záložního energetického zdroje. \\
\hline & & I.6.2.3. Výpadek chladící vody. \\
\hline & & $\begin{array}{l}\text { I.6.2.4. Porucha pneumatického/elektrického } \\
\text { měřícího a regulačního systému. }\end{array}$ \\
\hline & & I.6.2.5. Výpadek dodávky páry. \\
\hline & & I.6.2.6. Výpadek dodávky paliv. \\
\hline & & $\begin{array}{l}\text { I.6.2.7. Výpadek dodávky dusíku nebo jiných } \\
\text { inertních médií. }\end{array}$ \\
\hline
\end{tabular}

I.6.3. Dopad dopravní nehody uvnitř podniku na aparáty zařízení.

I.7. Události v okolí podniku ovlivňující zařízení:

I.7.1. Vliv domino efektu na zařízení následkem události v jiném zařízení sousedního podniku.

I.7.2. Dopad dopravní nehody vně podniku na aparáty zařízení.

I.7.3. Porucha veřejných sítí:

I.7.3.1. Výpadek elektrické sítě.

I.7.3.2. Výpadek vodovodního řadu.

I.7.3.2. Porucha v dodávce jiných médií a služeb $\mathrm{v}$ okolí důležitých pro podnik.

I.7.4. Činnost neoprávněných osob:

I.7.4.1. Sabotáže.

I.7.4.2. Ostatní akce (vandalismus, rozkrádání apod.).

I.8. Přírodní podmínky a pohromy:

I.8.1. Extrémní intenzita větru.

I.8.2. Nízká / vysoká teplota ovzduší.

I.8.3. Zemětřesení.

I.8.4. Povodeň.

I.8.5. Blesky.

\section{Doprovodné přičiny havárie:}

II.1. Manažerská / organizační opomenutí:

I.1.1. Nedostatek bezpečnostní kultury.

II.1.2. Neadekvátní organizace bezpečnosti.

II.1.3. Nedodržení předem stanovených bezpečných postupů (např. pro udržení nebo zvýšení výroby atd.).

II.1.4. Nedostatečné nebo nevhodné předpisy (pro pracovní postupy):

II.2. Nedostatky designu:

II.2.1. Nevhodné použití norem / prováděcích předpisů pro konkrétní výrobu (proces).

II.2.2. Proces nedostatečně analyzován z hlediska bezpečnosti, nebezpečí nebylo identifikováno.

II.2.3. Chyby v designu (opomenutí, nevhodné použití norem / předpisů).

II.2.4. Chyby v aplikaci ergonomických principů pro design vztahu člověk-stroj.

II.2.5. Použité normy/předpisy zajistily pouze omezenou ochranu.

II.3. Nedodržení příslušných pracovních předpisů (zkraty):

II.3.1. Výrobní předpisy.

II.3.2. Předpisy pro údržbu.

II.3.3. Předpisy týkající se testování, provozování, kalibrace nebo inspekce.

II.3.4. Předpisy konstrukční.

II.3.5. Předpisy pro vnitřní komunikaci.

II.3.6. Předpisy pro povolování prací.

II.3.7. Předpisy pro laboratorní analýzy.

II.3.8. Předpisy pro skladování materiálů. 
Tab. 2 Výběr př́čin ztráty soudržnosti zařizení v chemickém prưmyslu s připadným uvolněním nebezpečných chemických látek do okolního prostředí následkem ztráty obsahu (zádrže) zařizení.

Tab. 2 Selection of causes of loss of containment of facility in chemical industry with eventual release of dangerous chemical substances into surrounding as a consequence of loss of content (plug) of facility.

I. Závady soudržnosti zařízení způsobené „otevřeným koncem“ cesty do atmosféry.

A. Následkem uskutečněného odlehčení procesu nebo požadavků vypustit zařízení.

B. Následkem chybné operace nebo poruchy zařízení, nap̌r. nesprávnou činností pojišstovacího ventilu nebo poruchou pojištovací membrány, atd.

C. Následkem chyby operátora, nap̌r. ponechání otevřeného odvzdušňovacího nebo odkalovacího ventilu, špatné směrování přesunu materiálu, přeplnění zásobníku, otevření natlakované jednotky, atd.

II. Závady v soudržnosti způsobené v mezích operačních podmínek zařízení následkem vad zařizení.

A. Vady vzniklé před uvedením do provozu a neobjevené před najetím (následkem špatných inspekčních nebo zkušebních procedur).

1. Zařízení navržené neadekvátně pro zamýšlený výkon, např. vyspecifikován špatný materiál, neadekvátní jmenovitý tlak nádob nebo potrubí, neadekvátní jmenovitá teplota, atd.

2. Defekty vzniklé během výroby, např. použit špatný materiál, nízká zručnost pracovníků, nízká úroveň kontroly kvality, atd.

3. Poškození zařízení nebo zhoršení jeho stavu při dopravě nebo skladování.

4. Poruchy vzniklé při stavbě, např. defekty při svařování, porušení souososti, špatně přizpůsobená těsnění, atd.

B. Vady následkem zhoršení stavu zařízení př̀ provozu nezjištěné dříve, než se jejich vliv stal významným (např̀. nevhodné monitorovací procedury $\mathrm{v}$ těch př́padech, kdy zhoršování je postupné).

1. Zeslabení a trhliny v ucpávkách čerpadel nebo míchadel, těsnění ventilů, těsnění přírubových spojů, atd.

2. Interní a/nebo externí koroze, včetně popraskání vlivem pnutí z koroze.

3. Eroze nebo zeslabení.

4. Únava kovů nebo dopady vibrace.

5. Hrubé zacházení v předchozím údobí, např. provoz pece při teplotách převyšujících konstrukční teplotu trubek („,reep“ neboli tečení materiálu).

6. Zkřehnutí vodíkem.

C. Vady vzniklé při rutinní údržbě nebo při malých změnách neprovedených přesně, např. nízká zručnost pracovníků, špatné materiály, atd.

III. Závady v soudržnosti způsobené v mezích operačních podmínek zařízení následkem externích činitelů.

A. Poškození nárazem, napřr. pád jeřábu, silniční vozidlo, rypadlo, strojní dílna přidružená k procesní jednotce, atd.

B. Poškození ohraničenou explozí následkem nahromadění a vznícení hořlavých směsí vzniklých z malých úniků, např. výbušné prostředí vytvořené $\mathrm{v}$ analyzátorových domkách, $\mathrm{v}$ uzavřených kanalizacích, okolo obestavěných zásobníků, atd.

C. Sesedání stavebních podpěr následkem geologických nebo klimatických faktorů nebo vady stavebních podpěr následkem koroze, atd.

D. Poškození silničních cisteren, železničních vagónů, kontejnerů, atd. během přepravy materiálu do a z místa.

E. Vystavení vlivu požáru.

F. Dopady tlakové vlny z okolních explozí (exploze neohraničeného oblaku par, vybuchující nádoby, atd.), jako je přetlak v čele vlny, úlomky, poškození staveb, atd.

G. Prrírodní pohromy, jako je vichřice, zemětřesení, povodně, blesky, atd.

IV. Závady v soudržnosti způsobené následkem odchylek mimo meze operačních podmínek zařízení.

A. Přetlakování zařízení

1. Následkem propojení se zdrojem tlaku:

a. zdroj tlaku plyn:

(1) prudký vnik plynu do následujícího nízkotlakého zařízení v důsledku poruchy kontroly tlaku, chybně otevřený oddělovací ventil atd.

(2) tlakový zpětný tok do nízkotlakového zařízení, např. v důsledku poruchy kompresoru.

b. zdroj tlaku kapalina:

(1) načerpání blokovaných (ucpaných) plynových prostorů,

(2) hydraulické přetlakování jako následek blokování (ucpání) na odtokové straně,

(3) nadměrný ráz, takový jako při náhlém uzavření ventilu na transportním potrubí kapaliny.

2. Následkem vzrůstající teploty procesu:

a. ztráta chlazení:

(1) ztráta průtoku chladiva, např. do chladiče reaktoru, do kondenzátoru destilační kolony, atd.

(2) zvýšená teplota chladiva, např. výpadek ventilátoru chladící vody, atd.

(3) nános nečistot $\mathrm{v}$ chladičích, kondenzátorech, výměnících,

b. nadměrný vstup tepla (termálního)

(1) porucha kontroly vařáku, zejména u systémů vytápěných parou nebo horkým olejem, 
Tab. 2 Výběr přičin ztráty soudržnosti zařizení v chemickém prümyslu s prípadným uvolněním nebezpečných chemických látek do okolního prostředi následkem ztráty obsahu (zádrže) zařizení. (Pokračování)

Tab. 2 Selection of causes of loss of containment of facility in chemical industry with eventual release of dangerous chemical substances into surrounding as a consequence of loss of content (plug) of facility. (Continuation)

(2) vstup horkého materiálu z vnějšku, např. přetok,

c. nadměrný vznik tepla (chemického)

(1) ujetí reaktoru, např. následkem nedostatku reakčního rozpouštědla, vysoké rychlosti přívodu surovin, vysokého molárního poměru, nashromáždění nezreagovaných chemikálií při nevhodném míchání nebo dočasné ztrátě reakce následně vedoucí $\mathrm{k}$ ujetí reaktoru, atd.

(2) samozahřívání následkem vstupu katalytických nečistot, např. zpětný tok ze spotřebitelské jednotky ethylenoxidu do napájecího zásobníku,

(3) samozahřívání následkem smíchání reagujících chemikálií, např. $\mathrm{H}_{2} \mathrm{SO}_{4} \mathrm{~s} \mathrm{NaOH}$,

(4) exotermní rozklad tepelně nestabilních nebo explozivních materiálů, jako jsou peroxidy, např. následkem vzrůstu teploty, překoncentrováním nebo uložením na horké povrchy.

3. Následkem vnitřní exploze vzniklé vytvořením a zapálením směsí hořlavých plynů, aerosolů nebo prachů:

a. vnik ovzduší např. následkem neadekvátního vyčištění zařízení před najetím, následkem ztráty proplachu dusíkem v hlavách faklí, skladových zásobníků, odstředivkových systémů, sušáren, atd.

b. nepř́itomnost kritického inertního zřed'ovadla, např. dusíku ve skladových zásobnících s ethylenoxidem, výpadek dusíku ve směšovacích sekcích transportních systémů pevných látek, atd.

c. nedostatek prostředků tlumících explozi,

d. hořlavá odchylka v oxidačních procesech, např. následkem vysokých podílů ovzduší nebo kyslíku nebo př̀ zastavení konverze.

4. Následkem fyzikálně nebo mechanicky indukovaných sil nebo pnutí:

a. expanze při změně stavu, např. zamrznutí vody v potrubí,

b. tepelná expanze zablokovaných kapalin, např. ve výměnících tepla nebo v dlouhých potrubích,

c. vnik cizích fází, např. porucha plynového kompresoru následkem protlačení kapaliny sáním stroje, pulsování kondenzátu $\mathrm{v}$ parovodech, atd.

B. Podtlakování zařízení (neschopného odolat vakuu):

1. Př́mým připojením $\mathrm{k}$ ejektoru nebo $\mathrm{k}$ zařízení normálně provozovanému pod vakuem:

a. následkem selhání zařízení, napřr. ztrátou kapalinového uzávěru následkem poruchy hlídače hladiny a tím způsobeným spojením s vakuovým prostorem,

b. následkem chyby operátora, např. otevřený oddělovací ventil, atd.

2. Následkem pohybu nebo přemístění kapalin:

a. vyčerpání zásobníků nebo nádob,

b. vyprázdnění nebo gravitační odtok ze zvýšených zablokovaných zařízení.

3. Následkem ochlazení plynů nebo par:

a. kondenzace kondenzovatelných par, např. zablokování nádoby po vypařování,

b. chlazení nekondenzovatelných plynů a par, např. skladový zásobník při silném dešti v létě.

4. Následkem jevu rozpustnosti, např. rozpouštění plynů v kapalinách.

C. Vysoká teplota kovů (způsobující ztrátu pevnosti):

1. Požár pod zařízením, např. následkem výtoku, prosakování čerpadel, atd.

2. Plamenový náraz způsobující lokální přehřátí, např. v pecích následkem nesouososti nebo špatným seřízením hořáků.

3. Přehřátí elektrickými topidly, např. následkem poruchy vysokoteplotních pojistek.

4. Neadekvátní průtok tekutiny vytápěným zařizením, např. porucha trubky pece při ztrátě průtoku horkého oleje.

5. Vyšší průtoková rychlost nebo vyšší teplota teplejší páry nebo nižší průtoková rychlost nebo vyšší teplota chladnější páry výměníkem tepla.

D. Nízká teplota kovů (způsobující zkřehnutí a přepnutí):

1. Podchlazení chladící jednotkou, nap̌r. následkem poruch kontroly, použitím špatného chladiva, atd.

2. Neúplné odpaření a/nebo neadekvátní ohřátí chladného materiálu před převedením do zařízení nevhodné jmenovité teploty, např. následkem poruchy kontroly odparky kapalného etylénu.

3. Ztráta tlaku v jednotkách zpracovávajících kapaliny o nízkém bodu varu.

E. Špatné zpracovávané materiály nebo abnormální znečištění (způsobující větší korozi, chemické působení na ucpávky a těsnění, trhání korozním pnutím, zkřehnutí, atd.)

1. Změny složení par mimo př́pustné hranice.

2. Abnormální nečistoty vnesené se surovinami nebo nevhodné suroviny.

3. Vedlejší produkty nežádoucích chemických reakcí.

4. Kyslík, chlór nebo jiné nečistoty zůstávající v zařízení při najíždění následkem neadekvátní evakuace nebo dekontaminace.

5. Nečistoty vstupující do procesu z atmosféry, obslužných médií, úniků z potrubí, atd. během provozu. 
používanými v rizikovém inženýrství [9], tj. analýza situace, analýza kontrolním seznamem, analýza stromem událostí a multikriteriální vyhodnocení.

Při vyšetřování průmyslových nehod i havárií s přítomností nebezpečných chemických látek se obvykle zjistí, že nebyly způsobeny nějakou jedinou příčinou, nýbrž že vyplynuly z konkrétní kombinace celé řady okolností; nejčastěji jde o propojení př́icin lidských, technických, environmentálních a organizačních. Dále se obvykle zjistí, že závažným haváriím předcházely jisté události, tzv. „skoro-nehody“ (near-mises), které proběhly v podmínkách splňujících většinu havarijních okolností. Důkladným rozborem se obvykle zjistí, že i při kritické události, dopady nehod až závažných havárií mohou být velmi různorodé, od případů nevykazujících žádná zranění osob nebo poškození majetku či životního prostředí až po úmrtí osob a závažné škody na majetku a životním prostředí.

Analýzy procesů, které způsobily nehodu nebo až závažnou havárii ukazují, že nepřijatelné jevy nastaly jako výsledek jistého sledu jevů a měly i dlouhou inkubační dobu (např. postupné snižování důrazu na bezpečnostní pravidla a zásady). Proto je užitečné modelovat též kroky, jejichž uskutečněním je možné se havárii vyhnout. Přitom se vychází z modelu stromu událostí, které vyústily nebo mohou vyústit $\mathrm{v}$ havárii. Počáteční, též iniciační událost (Initiating Event) vyvolá řetězec jevů dle konkrétních podmínek v daném okamžiku. Potenciální nehoda až havárie se rozvine pouze tehdy, pokud současně vznikne nebo již probíhá spouštěcí událost (Trigger Event). Nežádoucí jev se uskuteční pouze tehdy, pokud selžou ochranná zařízení nebo zásahy obsluhy. Stupeň závažnosti jevu pak závisí na míre selhání zmírňovacích opatření. Uvedená „anatomie“ nehody popřr. havárie je převzata z odborné literatury proto, že vhodně spojuje základní počáteční př́íčiny a následné uvolnění hmoty nebo energie do okolního prostředí.

Při vyhodnocování dat získaných vyšetřováním závažných havárií s př́itomností nebezpečných chemických látek jsou identifikovány jednak bezprostředně přímé př́íčiny nehody a následné havárie, jednak doprovodné př́ičiny havárie. V tab. 1 je uvedena klasifikace faktorů, jejichž role při vzniku havárie je podstatná (přeloženo z práce [10]).

Všem průmyslovým nehodám a haváriím ve stabilních zařízeních s přítomností chemických látek je společné jedno stadium, které bývá $\mathrm{v}$ odborné literatuře označováno termínem „Loss of Containment“ a znamená v chemickém průmyslu ztrátu soudržnosti nádoby či objektu. Proto je třeba upozornit, že v chemické průmyslové praxi je rozdíl oproti jaderné energetice, ve které je kontejnment realizován jako ochranná obálka reaktorové haly se všemi svými vlastnostmi a funkcemi. Podobný technický objekt se v chemickém průmyslu vyskytuje velmi zř́́dka a jen v několika zvláštních př́ípadech chrání zařízení bezpečnostní obálka - kontejnment. Většina velkých zařízení, jak výrobních, tak skladovacích, je obvykle postavena na volných prostranstvích a jejich zařízení se zpravidla nacházejí pod širým nebem. Proto jakákoliv porucha $\mathrm{v}$ kterémkoliv místě technologického systému znamená ztrátu soudržnosti (také ztrátu obsahu nebo zádrže) tohoto systému a únik nebezpečné chemikálie do okolního prostředí, tj. na terén a do ovzduší. Některé, zejména malé úniky neboli úkapy, jsou nezbytné a vznikají zejména při přečerpávání chemikálií, protože zvláště některá čerpadla (ucpávková) nejsou nikdy absolutně těsná.
Příčiny úniku nebezpečné chemické látky z uzavřeného systému následkem ztráty soudržnosti zařízení jsou rozvedeny v tab. 2, přeložené z práce [11].

\section{POUČENÍ Z NEHOD A HAVÁRIÍ}

Studiem nehod mohou provozovatelé omezit nebezpečné nebo neproduktivní pracovní praktiky a tím zvýšit kulturu bezpečnosti práce. Pozitivní zpětnou vazbu na vznik nehod mohou mít i audity řízení, audity bezpečnosti, audity nebezpečných dějů, chemických reakcí, zprávy o nehodách a skoro nehodách, a monitoring dodržování všech opatření. Existují 3 kategorie nebo „úrovně“ doporučení, a to:

1. Bezprostřední technická doporučení.

2. Doporučení pro zabránění nebezpečí.

3. Doporučení pro řízení zaměřené na primární prríčiny nehod.

Bezprostřední technická doporučení jsou zaměřena na zabránění určitých nehod. Např. u odběru vzorků kapalného chloru ve výrobně chloru existuje určité nebezpečí úniku chlóru a následná inhalace plynného chloru obsluhou při vzorkování chloru. Doporučení z této kategorie jsou: změna techniky vzorkování, trénink správného odběru a použití ochranných pomůcek.

Doporučení pro zabránění (odvrácení) havárií jsou zaměřena na odvrácení nepřijatelných havárií anebo alespoň jejich nepřijatelných dopadů. Např. se provede zlepšení běžných, oddělujících opatření umístěných mezi obsluhu a vlastní nebezpečí, tj. modifikace vzorkovací aparatury, vzorkováním v jiném místě nebo in-line analyzátorem, který odstraňuje potřebu ručního vzorkování.

Doporučení pro řizení zaměřené na primární př́ǐiny nehody. Analýzou situace se identifikují nutné změny v řídicích systémech. Jde nejen o prevenci daného typu nehody, ale i na jiné podobné nehody. Předmětná opatření jsou více důsledná a déle přetrvávající. V př́ípadě vzorkování chlóru to může být:

a) zlepšení v metodách odběru vzorků (sofistikovaně se odpoví na otázky: Kdo se účastní rozhodování? Jaká jsou kritéria pro stanovení místa odběru? Jaké jsou metody odběru a př́strojové vybavení? Kdo je oprávněn k odběru? Existuje periodický audit? a odpovědi se zavedou do praxe);

b) zlepšení v systému řízení pro zaváděcí, hodnotící a monitorovací standardní výrobní postupy (jsou postupy adekvátní, srozumitelné a jsou důsledně prováděny? Je tento pracovní úkol stále nezbytný?), a odpovědi se zavedou do praxe;

c) existuje rutinní postup jako analýza bezpečnosti práce, ve kterém jsou úkoly systematicky posuzovány z hlediska potenciálního nebezpečí?

\section{ZÁVĚR}

OECD $[5,6]$ na základě rozsáhlých analýz havárií experty doporučila nutnost zavádění programu na zvyšování bezpečnosti a stanovila jeho zásady a koncept. Zároveň zdůraznila roli poučení $\mathrm{z}$ havárií a skoro-nehod; $\mathrm{v}$ rámci kultury bezpečnosti by poučení měla být systematicky používána vždy při zvažování technických a organizačně - rrídících opatření. Profesor Kletz, který zkoumal 
havárie, poukazuje na problém udržování a využivání znalostí $\mathrm{v}$ rámci dané organizace $[5,6]$. S postupem času a změnami personálu jsou původní opatření provedená po proběhlé havárii zapomenuta nebo nejsou předána všem pracovníkům $\mathrm{v}$ dané organizaci. Proto navrhuje následující opatření ke zlepšení společné paměti organizace:

1. Připojení poznámky ke každému pokynu, předpisu nebo normě, proč je právě takový.

2. Popis staré i nedávné havárie v podnikovém tisku s poučeními z nich vyplývající a projednání na školeních, zaměřených na bezpečnost, pro všechny složky podniku.

3. Pravidelná kontrola dodržování vydaných opatření.

4. Odstranění existujícího zařízení teprve po poznání, proč bylo instalováno. Rušení původního postupu po zjištění, proč byl přijat. Je to nutné, aby se neodstranilo něco, co má zabránit havárii nebo má zmírnit její dopady.

5. Zavedení lepšího informačního systému pro nalezení podrobností o haváriích a vydaných doporučeních po havárii.

Zavádění nových technologií s sebou nese i rizika, proto je třeba důsledně dbát na bezpečnost, což znamená kontinuální shromažd'ování relevantních dat, znalost metod rizikového inženýrství a provádění řízení procesů, hlavně složitějších, složitých a vzájemně propojených, způsobem, který vede k bezpečné komunitě, tj. každé průmyslové zařízení je bezpečné a neohrožuje sebe ani své okolí při svých kritických podmínkách.

Práce [12] se zabývá riziky, která narušují bezpečnost technických děl a jejich okolí. Ukazuje, že kvůli složitosti současných technických děl je nutno u důležitých technických děl, do kterých patř́ průmyslové komplexy, zvažovat i rizika, která jsou spojena s vnitřními propojeními, což potvrzují údaje v obou tabulkách. Proto v př́ipadě strategických řešení problémů technických děl je nutné používat systémové pojetí, založené na integrálním riziku.

Postupy založené na vypořádání dílčích rizik či integrovaného rizika nezajišt'ují dostatečně bezpečné technické dílo. Vzhledem $\mathrm{k}$ dynamickému vývoji světa je třeba prioritní rizika monitorovat a vypořádávat $\mathrm{v}$ čase. Na základě porovnání uspořádaných požadavků technik používaných při práci s riziky $\mathrm{v}$ technickém díle byl v práci [12] sestrojen kontrolní seznam pro posuzování míry bezpečnosti technických děla na základě posouzení úrovně sedmi oblastí technik práce s riziky. Př́iklad hodnocení bezpečnosti běžných technických děl, která nepatř́i mezi kritické objekty České republiky a mají charakter SME, ukázal, že jejich míra bezpečnosti je kolem rozhraní malá a střední. To znamená, že dle [11] jsou úrovně prevence nehod a havárií a připravenost na jejich rychlé a správné zvládnutí nízké.

\section{LITERATURA}

[1] PROCHÁZKOVÁ, D., BUMBA, J., SLUKA, V., ŠESTÁK, B. Nebezpečné chemické látky a chemické př́pravky a prümyslové nehody. PA ČR, Praha, 2008, 420 s. ISBN 978-80-7251-275-1

[2] PROCHÁZKOVÁ, D.: Strategické rízeni bezpečnosti území a organizace. ČVUT, Praha, 2011, $483 \mathrm{~s}$. ISBN 978-80-01-04844-3.

[3] PROCHÁZKOVÁ, D.: Analýza a ř́zení rizik. ČVUT, Praha, 2011, 405 s. ISBN 978-80-01-04841-2

[4] PROCHÁZKOVÁ, D.: Bezpečnost kritické infrastruktury. ČVUT, Praha, 2012, 318 s. ISBN 978-80-01-05103-0

[5] OECD. Guiding Principles on Chemical Accident Prevention, Preparedness and Response. OECD, Paris, 2003, $192 \mathrm{~s}$.

[6] OECD. Guidance on Safety Performance Indicators. Guidance for Industry, Public Authorities and Communities for developing SPI Programmes related to Chemical Accident Prevention, Preparedness and Response. OECD Environment, Health and Safety Publications, 11, OECD, Paris, 2003, 207 s.

[7] AIChE. DOW's Chemical Exposure Index Guide. $1^{\text {st }}$ Edition, AIChE, New York, 1994.

[8] ČVUT: Archiv - analýza a hodnocení rizik pohrom, havárií a dalších jevü. ČVUT, Praha, 2017.

[9] PROCHÁZKOVÁ, D. Metody rizikového inženýrství. SPBI SPEKTRUM XVIII, Ostrava, 2012, 147 s. + CD ROM (106 s., $690 \mathrm{kB})$.

[10] DROGADIS, G. Major Accident Reporting System. Elsevier, Amsterdam, 1993.

[11] PETROCHEM. Loss Prevention. PCHE - PetroChemEng, Praha, 2004. ISBN 80-02-01574-6

[12] PROCHÁZKOVÁ, D. Nástroj pro stanovení úrovně bezpečnosti technického díla na základě posouzení validity technik používaných při práci s riziky v praxi. Řizení rizik procesů spojených s technickými díly, ČVUT, Praha, 2017, s. 163-191. ISBN 978-80-01-06351-4. http://hdl.handle.net/10467/73522

[13] PROCHÁZKA, J., PROCHÁZKOVÁ, D. Nehody a havárie v průmyslu. XXVII. Mezinárodni védecká konference soudního inženýrství (ExFoS 2018), 1.-2. 2. 2018, Brno. Sborník př́spěvků konference Expert Forensic Science Brno 2018. s. 604-620. ISBN 978-80-214-5600-6

\section{Správná citace:}

PROCHÁZKA, J., PROCHÁZKOVÁ, D. Nehody a havárie v průmyslu. Soudní inženýrství, 2018, 29(3), 37-45. ISSN 1211-443X. 